\title{
Primary fixation of mini slings: a comparative biomechanical study in vivo
}

Paulo Palma, Rodrigo Teixeira Siniscalchi, Luiz Carlos Maciel, Miguel Angel Bigozzi, Inacio Dal Fabbro, Cassio Riccetto

Division of Female Urology (PP, MAB, CR), Biomaterial Research Unit (RTS, LCM, CR) and Mechanical Properties of Biological Materials Laboratory (IDF) - University of Campinas - Sao Paulo, Brazil

\section{ABSTRACT}

Introduction and Objectives: The mini sling concept for stress urinary incontinence is an anatomical approach that involves placing a midurethral low-tension tape anchored to the obturator internus muscles bilaterally. They overcome the blind passage of long needles and all the related complications. There are many different devices available and because these are outpatient procedures, primary fixation plays an important role in the outcome. The objective is to evaluate the primary fixation of the various devices of attachment of the commercially available mini-slings through biomechanical tests.

Materials and Methods: A total of 45 Wistar rats were divided in 3 groups of 15 rats each. They underwent 5 subcutaneous implantation of different mini slings and one polipropilene mesh (control), as follows: TVT-Secur ${ }^{\circledR}$ (Gynecare, USA), Type 1 polypropylene mesh (control); Ophira Mini Sling System ${ }^{\circledR}$ (Promedon, Argentina), Tissue Fixation System ${ }^{\circledR}$ (TFS PTY, Australia), Zipper Sling ${ }^{\circledR}$ and "T device" (Prosurg, USA). The abdominal wall was removed on bloc at different times after implant for biomechanical evaluation, which consisted in application of unidirectional force to the extremity of the fixation system or mesh, until it was completely removed from the tissue using a tension meter (Nexygen 3.0 Universal Testing Machine - LLOYD Instruments). The force was measured in Newtons (N).

Results: There was significant difference in the resistance to extraction among the different fixation systems. At 7 days the Ophira Mini Sling System ${ }^{\circledR}$ presented the best fixation and "T dispositive" the worst.

Conclusion: Ophira mini sling System ${ }^{\circledR}$ presented the best primary fixation at $7^{\circ}, 14^{\circ}$ and $30^{\circ}$ days. The impact of this feature in the clinical setting needs to be verified.

\section{ARTICLE INFO}

\section{Key words:}

urinary incontinence; suburethral sling; outcomes

Int Braz J Urol. 2012; 38: 258-66

Submitted for publication:

April 11, 2011

Accepted after revision: November 17, 2011

\section{INTRODUCTION}

The understanding of the physiopathology of Stress Urinary Incontinence (SUI) has constantly improved over the two last decades, since the presentation of the Integral Theory (1) and TVT introduction (2). In spite of the good cure rate reported with TVT, severe complications such as visceral and vessels injuries have been described (3). As an alternative to TVT, Delorme introduced the transobturator tape (TOT) $(4,5)$ with successful results. In spite of the low intraoperative complication rate of TOT, most complications were related to the blind passage of 
needles through the obturator foramen (3), which leaded to the creation of small minimally invasive devices which avoid this passage and can be implanted under local anesthesia, on an outpatient basis and with minimal dissection. Due to a shorter insertion path, it is expected that some complications such as vesical perforation, vascular injuries, perineal fasciitis and reduction of postoperative pain in the area of adductor muscles can be reduced $(6,7)$. It is possible to suppose that the greater adhesion of the mesh to host tissues and the lower the amount of implanted material lower the risk of extrusion and the rate of sexual discomfort, respectively.

Initial results with some mini sling systems were disappointed although they were appealing. The first results reported with TVT-Secur showed success rates 10\% lower than could have been expected with other types of slings (8-10). Therefore, the proposal of biomechanical studies is justified in order to understand the physiopathological process associated to sling efficacy itself. Up to this moment, no studies have been published in literature comparing the tissue fixation capacity of the different types of mini slings.

In this original experimental study, the primary fixation of the different anchoring devices of some commercially available mini slings and experimental devices is evaluated "in vivo" through biomechanical tests.

\section{MATERIALS AND METHODS}

This study was approved by the Ethics Committee for Animal Research of the University of Campinas and there is no conflict of interest. Forty-five Wistar rats (weight between $150 \mathrm{~g}$ and 200g), aged 8 weeks were divided into 3 groups of 15 rats each. Animals were intravenously anesthetized with sodium pentobarbital at 6\% and were positioned in horizontal dorsal decubitus after abdominal trichotomy and asepsis with Povidone-iodine. A $2 \mathrm{~cm}$ transverse incision was then made in the lower abdomen. After the dissection, five different types of mini sling anchoring devices and one polypropylene mesh (control) were implanted between the subcutaneous cellular tissue and the abdominal muscle fas- cia, namely: TVT-Secur ${ }^{\circledR}$ (Gynecare, USA), polypropylene mesh (PP-control), Ophira Mini Sling System ${ }^{\circledR}$ (Promedon, Argentina), Tissue Fixation System ${ }^{\circledR}$ (TFS PTY, Australia), Zipper Sling ${ }^{\circledR}$ and "T device" (Prosurg, USA) (Figure-1).

The five samples of each device were randomly implanted in each group (two per animal - one in each side of abdominal wall) (Figure-2). After implantation of the anchoring devices of the mini slings, the skin was sutured, taking care to avoid that the mesh was in direct contact with the skin suture.

The evaluation of the tensile resistance was made in a fresh fragment of the abdominal wall of the rat. After an observation period (7, 14, 30 days) the animals were divided in 3 groups and euthanized, as follows: Group 1 (15 rats euthanized at day 7); Group 2 (15 rats euthanized at day 14); and Group 3 (15 rats euthanized at day 30).

The abdominal wall was removed and symmetrically divided into 2 blocks containing the implanted anchoring device. Subsequently, approximately $2 \mathrm{~mm}$ of the extremity of the devices were dissected to be pulled so that they

\section{Figure 1 - Devices.}

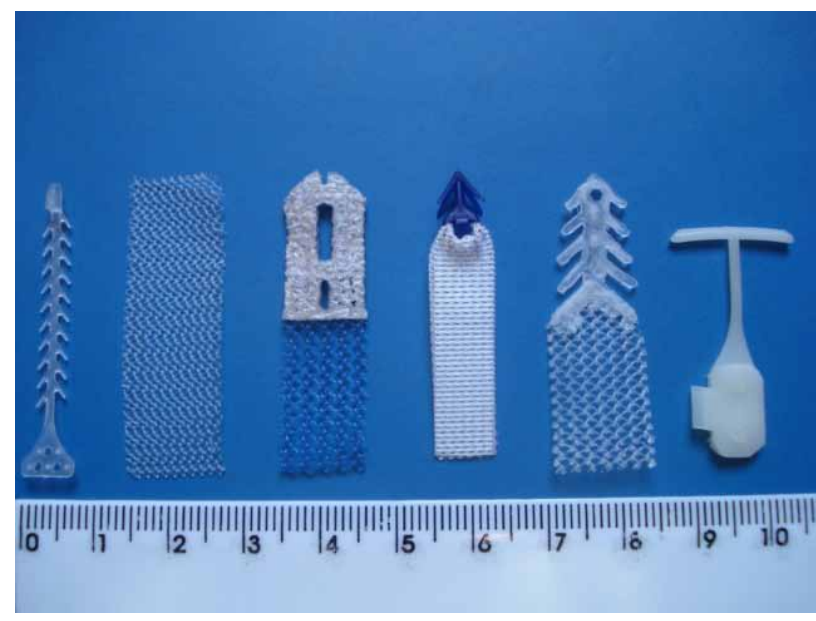

$1^{\circ}$ ) Ophira mini sling system $\circledast$ (Promedon, Argentina)

$2^{\circ}$ ) Polypropylene Mesh (Promedon, Argentina)

$3^{\circ}$ ) TVT-Secur $\circledast$ (Gynecare, USA)

$4^{\circ}$ ) Tissue Fixation System $®$ (TFS PTY, Australia)

$5^{\circ}$ ) Zipper Sling ${ }^{\circledR}$ (Prosurg, USA)

$6^{\circ}$ ) Prosurg $\circledast$ (Prosurg, USA) 
Figure 2 - Surgical Tecnhique.

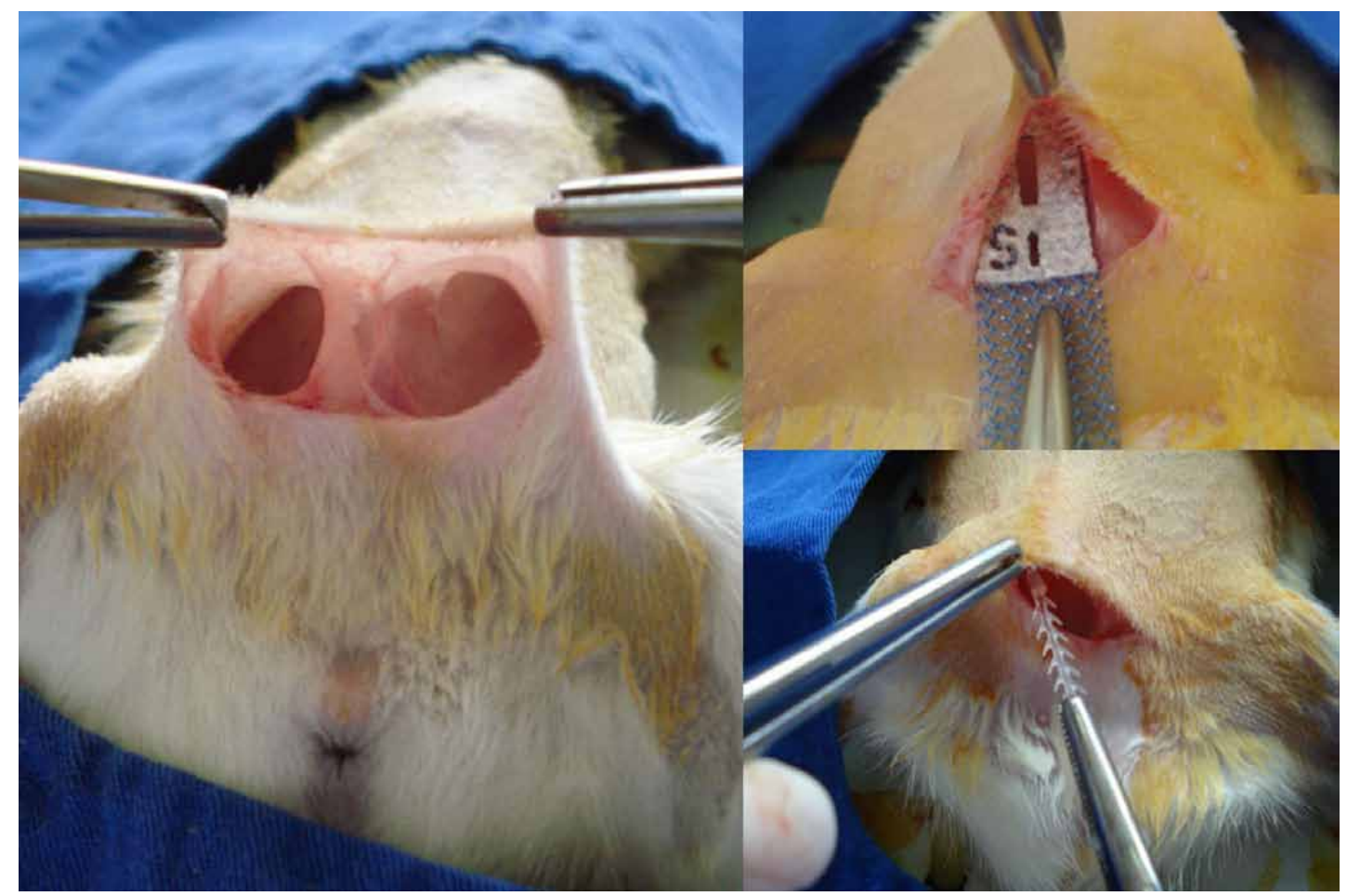

could be adapted to the fastener of the tension meter ("Nexygen 3.0 Universal Testing Machine" - LLOYD Instruments) which is specially intended for load tests in soft tissues (11). The opposite portion of the fragment, containing the abdominal wall without the device, was fixed to the lower fastener of the tension meter and a biomechanical study was performed, in order to measure their tissue adherence at different times.

Next, an increasing load was applied to the extremity of the anchoring device or mesh until it was completely removed from the tissue (Figure-3). The load was measured in Newtons (N), so higher load values show a greater fixation of the device to the tissues. We applied an increasing force $(\mathrm{N})$ and constant speed $(2 \mathrm{~mm} / \mathrm{sec})$. The strength and the time varied for each test. As the time was not relevant to our study, only the force was measured.

In order to compare the maximum load in relation to the groups over the time $(7,14$ and 30 days), the Analysis of Variance (ANOVA) was used and the level of significance adopted was 5\%.

\section{RESULTS}

There was a significant difference of the maximum load needed for detachment of the mini slings anchoring devices from the tissues.

After 7 days of the placement of the implant, it was observed that Ophira Mini Sling System ${ }^{\circledR}$ showed the highest maximum load fixation $(6.21 \pm 0.52 \mathrm{~N})$ and the "T device", the worst fixation $(1.50 \pm 0.72 \mathrm{~N})$. There was no significant differences among the other devices.

On $14^{\text {th }}$ day after the implant, it was observed that Ophira Mini Sling System ${ }^{\circledR}$ and TFS showed the highest maximum load $(11.77 \pm 0.45$ $\mathrm{N}$ and $11.63 \pm 0.92 \mathrm{~N}$, respectively), compared to the other devices, which presented similar results. After 30 days, it was observed that Ophira Mini Sling System ${ }^{\circledR}$ showed the highest maximum 
Figure 3 - Experiment.

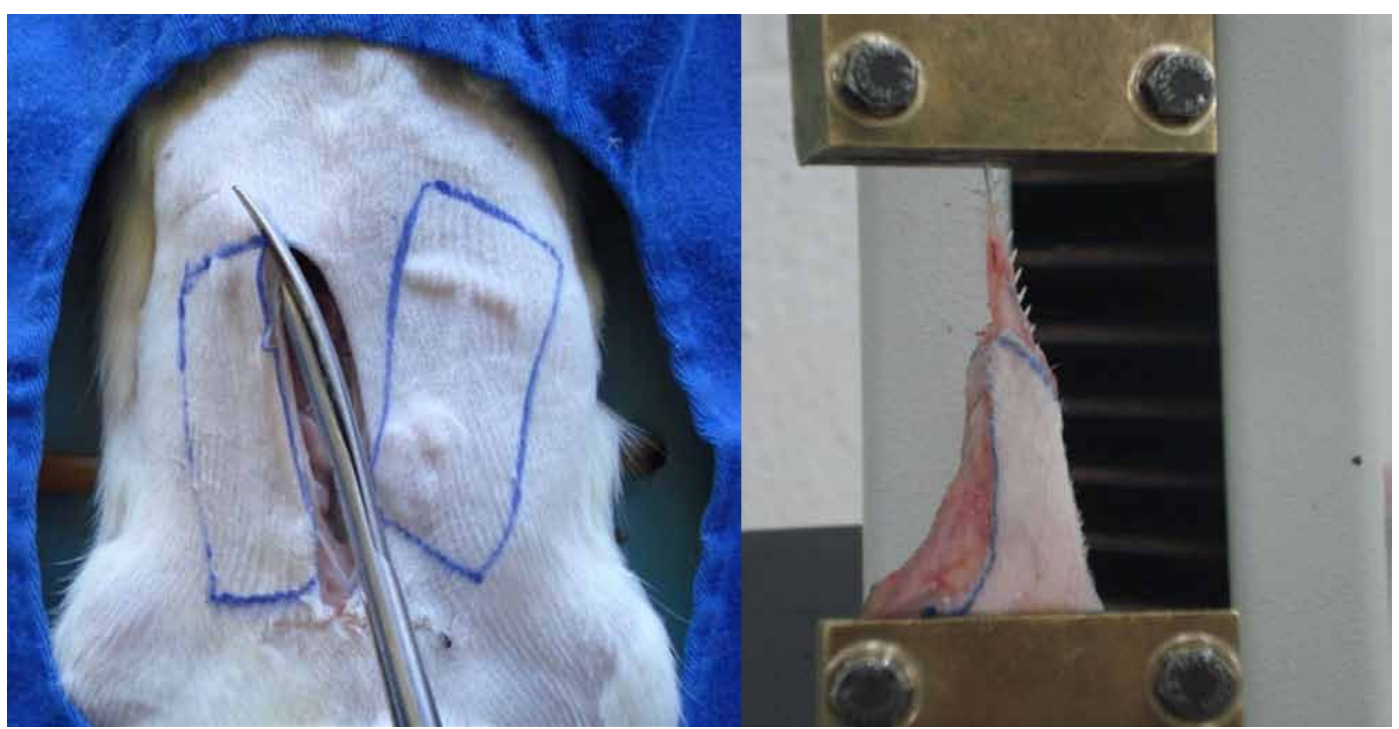

load $(18.30 \pm 0.55 \mathrm{~N})$ and the "T device" showed the worst fixation $(11.24 \pm 0.23 \mathrm{~N})$ (Tables 1 to 3 and Figure-4).

\section{DISCUSSION}

Since the introduction of the mini slings on the market, the failure rate that has been published by different authors differs markedly. Neuman published with TVT Secur ${ }^{\circledR}$ a prospective study showing a cure rate of $93.5 \%$ at 12 -month follow-up [n: 100] (12). In other study Solà Dalenz et al. presented $100 \%$ of cure at 2-month follow-up with TVT Secur ${ }^{\circledR}$ [n: 16] (13). Gorlero et al. studied 15 patients, and reported a negative stress test in $86.7 \%$ with TVT Secur ${ }^{\circledR}$ at 6-month follow-up (14). In contrast, Meschia and Debodinance published an objective cure rate of $70.4 \%$ and $81 \%$ at 6-month follow-up [n: 110] and 15-month followup [n: 95] respectively $(9,15)$.

Palma et al. have published preliminary results with arcus to arcus microsling. After 12 months, $88 \%$ of patients were dry, 5.5\% improved and 5.5\% incontinent [n: 20] (16).

The cure rates related to Mini Arc (American Medical Systems, USA) are different. Moore et al. reported a negative stress test in $90 \%$ of patients treated at 12-week follow-up [ $n=59]$ (17). Jiménez et al. published satisfactory results with a negative stress test in 90\% of patients, with a mean followup of 101 days after treatment with MiniArc [ $\mathrm{n}=$ 41] (18) and Debodinance and Delporte have found an objective cure rate of 75.7\% at 2-month followup [ $\mathrm{n}=72]$ (19). Mini Arc was not included in this experiment because when the study was performed it was not available in the market yet.

One can assume that the rationale for the use of the mini slings is based on its capacity of fixation to the host tissue immediately after the implant, which is probably the main factor for achieving the continence and lowering the risk of vaginal exposure or extrusion.

To date, few cases of vaginal exposure of the mini slings have been described. One case of exposition was reported by Martan et al. (20) and Hazewinkel et al. (21), respectively with TVT Secur ${ }^{\circledR}$ and only two cases were reported by Debodinance et al. with the same mini sling.

Tissue reactions to different types of synthetic materials used to repair the defects of the pelvic floor are almost established and have not been dealt with in this study (22-25). It is known that, apart from the mechanical properties of the implanted material, local factors such as tissue 
Table 1 - Loads for group and time (days).

\begin{tabular}{|c|c|c|c|c|c|c|}
\hline Group & Time & Mean (N) & SD & Minimum (N) & Median (N) & Maximum (N) \\
\hline \multirow[t]{3}{*}{ TFS } & 7 & 5.02 & 0.74 & 3.99 & 4.88 & 5.88 \\
\hline & 14 & 11.63 & 0.92 & 10.80 & 11.37 & 13.00 \\
\hline & 30 & 15.66 & 1.19 & 14.99 & 15.10 & 17.77 \\
\hline \multirow[t]{3}{*}{ TVT } & 7 & 4.45 & 0.49 & 3.99 & 4.18 & 5.10 \\
\hline & 14 & 8.98 & 0.19 & 8.66 & 9.02 & 9.13 \\
\hline & 30 & 14.00 & 0.52 & 13.25 & 14.10 & 14.66 \\
\hline \multirow[t]{3}{*}{ T device } & 7 & 1.50 & 0.72 & 0.76 & 1.58 & 2.53 \\
\hline & 14 & 7.25 & 0.99 & 5.75 & 7.76 & 8.12 \\
\hline & 30 & 11.24 & 0.23 & 10.99 & 11.37 & 11.48 \\
\hline \multirow[t]{3}{*}{ Mesh } & 7 & 3.80 & 0.72 & 3.04 & 3.50 & 4.66 \\
\hline & 14 & 8.31 & 0.47 & 7.90 & 8.10 & 9.01 \\
\hline & 30 & 13.36 & 0.64 & 12.99 & 13.01 & 14.48 \\
\hline \multirow[t]{3}{*}{ Ophira } & 7 & 6.21 & 0.52 & 5.74 & 6.06 & 7.09 \\
\hline & 14 & 11.77 & 0.45 & 10.99 & 11.90 & 12.10 \\
\hline & 30 & 18.30 & 0.55 & 17.88 & 17.99 & 19.10 \\
\hline \multirow[t]{3}{*}{ Prosurg } & 7 & 4.84 & 0.19 & 4.64 & 4.74 & 5.13 \\
\hline & 14 & 9.74 & 0.44 & 9.12 & 9.87 & 10.23 \\
\hline & 30 & 15.60 & 0.60 & 15.09 & 15.37 & 16.50 \\
\hline
\end{tabular}

Table 2 - Results of the ANOVA with repeated measures (in ranks) to Maximum Load.

\begin{tabular}{ll}
\hline Source variation & $p$-value \\
\hline Group & 0.0001 \\
Time & 0.0001 \\
Comparison of each group along the time & 0.0088 \\
\hline
\end{tabular}

tropism, infections and the surgical technique are directly related to the rates of extrusion $(26,27)$.

Since most of the modern slings have been built with materials with well-known biocompatibility, the surgeon's interest has been focused on the design of the fixation devices and implant instruments like needles and trocars. Although a variety of experimental models can be proposed for the study of such dispositives, one which allows for uniaxial stress test seems to be suitable for biomechanical evaluation, since in the vaginal environment the slings are not prone to rotational or centripetal forces.

The trend to perform slings in an outpatient basis had been first proposed in the nineties, along with the retropubic minimally invasive midurethral slings, but till now it has never been fully adopted because of safety reasons. The mini slings can turn this concept to a real possibility, since most of the clinical data shows a high level of safety. Therefore, as the patient can come back 
Table 3 - P-values for comparisons along time in each group (Contrast Test).

\begin{tabular}{lllllll}
\hline Times (days) & Ophira & Mesh & T-Device & Pro-surg & TFS & TVT \\
\hline 7 versus 14 & 0.0001 & 0.0002 & 0.0002 & 0.0002 & 0.0010 & 0.0014 \\
7 versus 30 & 0.0001 & 0.0001 & 0.0001 & 0.0001 & 0.0001 & 0.0001 \\
14 versus 30 & 0.0001 & 0.0001 & 0.0003 & 0.0001 & 0.0027 & 0.0001 \\
\hline
\end{tabular}

Figure 4 - Maximum Load - Comparison of different fixation devices.

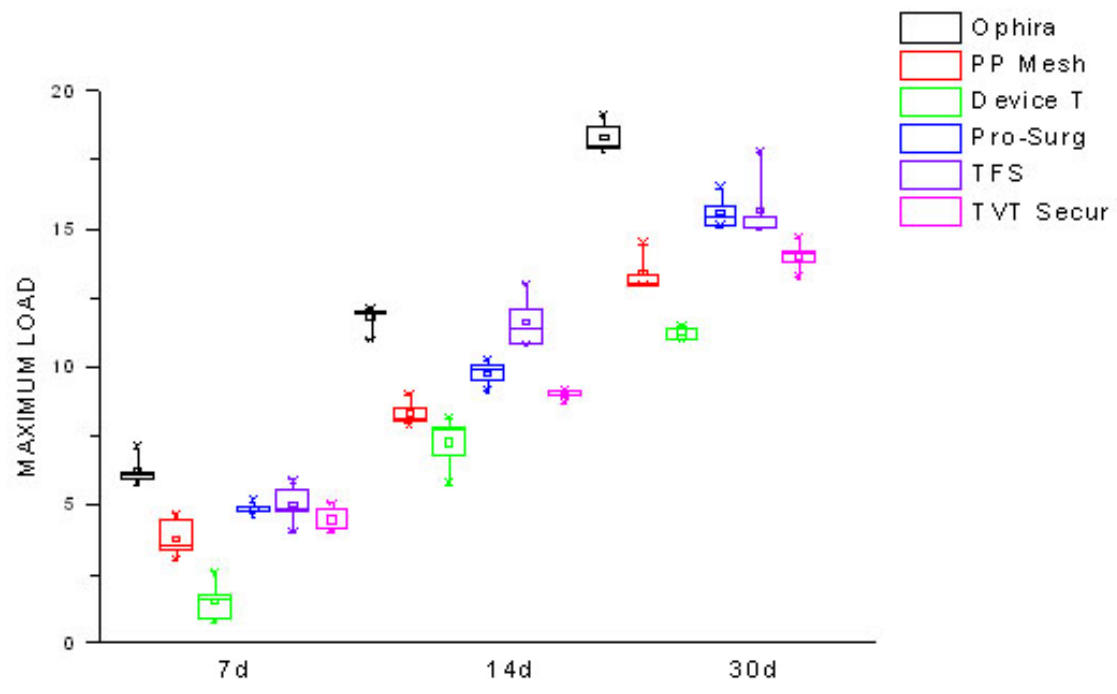

home in the same day of the procedure, the primary fixation of the sling becomes relevant.

The highest maximum load showed by Ophira Mini Sling System ${ }^{\circledR}$ probably is related to its multipoint fishbone-like polypropylene fixation device. But it is not possible to determine the minimal load which is sufficient to prevent sling misplacing in the clinical setting. TVT-Secur ${ }^{\circledR}$ and Zipper ${ }^{\circledR}$ fixation device slings have not been effective due to the fact that their stabilization on site depends mainly of the in growth of host fibrotic tissue. Previous experimental data showed that in the integration of monofilament polypropylene tapes, the formation of a mature conjuntive tissue around the mesh takes more than ninety days after the implant (28).
Polypropylene is a synthetic, inert, hydrophobic and non-absorbable material. Implants made of this have shown experimentally better tissue integration when compared to other synthetic materials. Other materials and coatings were studied for clinical use but have not demonstrated superiority to the polypropylene type I (28).

The response to foreign body is a physiological cascade triggered by the adhesion of proteins to the implant and, consequently, recruitment of inflammatory cells $(29,30)$. The phases of tissue repair may be classified as: early or hemostasis and inflammation; proliferation phase and final phase, in which the maturation of collagen occurs (31). In the integration of synthetic mesh one can consider the occurrence of a similar process. Based on this, we 
can infer that for any implant, the duration of each step may vary depending on various factors such as conditions of the host immune system, degree of bacterial contamination site and biocompatibility of implanted material. The complete resolution of the inflammatory response, represented by the reconstitution of the native tissue, may eventually not be possible due to the maintenance of aggression factors related to the physical and chemical properties of the implant. Thus, what is called integration is the end result of the interaction between the implant and the host, which is usually represented by varying degrees of fibrosis (32).

As the interface between the mesh and the host tissues is less extensive than in a conventional transobturator sling, a powerful fixation is necessary to stabilize the sling in the proper position in the early phase of the healing process. So, researchers should find ways to design fine but reliable biomaterials in order to improve results with minimal risk of recurrence of the incontinence or adverse events.

\section{CONCLUSIONS}

Ophira Mini Sling System ${ }^{\circledR}$ showed the best primary fixation at 7,14 and 30 days. At day 14, Ophira ${ }^{\circledR}$ and TFS $^{\circledR}{ }^{\circledR}$ were equally satisfactory. In addition, TVT-Secur ${ }^{\circledR}$ and Zipper ${ }^{\circledR}$ slings have not been effective due to the fact that they depend on tissue integration. These findings could influence clinical practice for outpatient procedures in which an effective primary fixation is needed.

\section{CONFLICT OF INTEREST}

None declared.

\section{REFERENCES}

1. Petros PE, Ulmsten UI: An integral theory and its method for the diagnosis and management of female urinary incontinence. Scand J Urol Nephrol Suppl. 1993; 153: 1-93.

2. Ulmsten $U$, Henriksson L, Johnson P, Varhos G: An ambulatory surgical procedure under local anesthesia for treatment of female urinary incontinence. Int Urogynecol J Pelvic Floor Dysfunct. 1996; 7: 81-5; discussion 85-6.
3. Petros PE, Richardson PA: Midurethral Tissue Fixation System sling -- a 'micromethod' for cure of stress incontinence -- preliminary report. Aust N Z J Obstet Gynaecol. 2005; 45: 372-5.

4. Palma P, Riccetto C, Dambros M, Fraga R: Pre pubic sparc: A promising alternative for selected cases of USI. Revista Urología Panamericana. 2003; 15: 19-21.

5. Delorme E: La bandelette trans-obturatrice: un procédé mini-invasif pour traiter l'incontinence urinaire d 'effort de la femme. Prog Urol. 2001; 11: 1306-13

6. Urwin GH, Heaton SR: The MiniArc (TM) single-incision sling system for female stress urinary incontinence: early results. Bju Int. 2008; 101: 26.

7. Kennelly M, Moore R, Keil K, Nguyen J, Lukban J: Shortterm assessment of MiniArc (TM) sling for the treatment of female stress urinary incontinence. Int Urogynecol J. 2008; 19: S24.

8. Jiménez Calvo J, Hualde Alfaro A, Raigoso Ortega 0, Cebrian Lostal JL, Alvarez Bandres S, Jiménez Parra J, et al.: Our experience with mini tapes (TVT Secur and MiniArc) in the surgery for stress urinary incontinence. Actas Urol Esp. 2008; 32: 1013-8.

9. Meschia M, Barbacini P, Ambrogi V, Pifarotti P, Ricci L, Spreafico L: TVT-secur: a minimally invasive procedure for the treatment of primary stress urinary incontinence. One year data from a multi-centre prospective trial. Int Urogynecol J Pelvic Floor Dysfunct. 2009; 20: 313-7.

10. Roovers J, van Dessel N, Vervest H, den Boon J, Milani F, Hinoul $P$ : TVT-secur: prospective data of outcome, complication risk and patients satisfaction. Int Urogynecol J. 2008; 19: S7-S8.

11. Martins PALS, Jorge RMN, Ferreira AJM: A Comparative Study of Several Material Models for Prediction of Hyperelastic Properties: Application to Silicone-Rubber and Soft Tissues. Strain. 2006; 42: 135-47.

12. Neuman M: Perioperative complications and early follow-up with 100 TVT-SECUR procedures. J Minim Invasive Gynecol. 2008; 15: 480-4

13. Solà Dalenz V, Ricci Arriola $P$, Pardo Schanz J: Stress urinary incontinence surgical correction with third generation submid-urethra sling: TVT-secur. Actas Urol Esp. 2008; 32: 522-9.

14. Gorlero F, Lijoi D, Glorio M, Mistrangelo E, Nicoletti A, Ferrero $S$, et al.: A new technique for surgical treatment of stress urinary incontinence: the TVT-secur. Minerva Ginecol. 2008; 60: 459-68.

15. Debodinance P, Lagrange E, Amblard J, Lenoble C, Lucot JP, Villet $R$, et al.: TVT Secur: more and more minimally invasive. Preliminary prospective study of 110 cases. J Gynecol Obstet Biol Reprod (Paris). 2008; 37: 229-36.

16. Palma P, Riccetto C, Reges R, Fraga R, Miyaoka R, Hermann V, et al.: Arcus to arcus microsling: technique and preliminary results. Int Urogynecol J Pelvic Floor Dysfunct. 2008; 19: 1133-6.

17. Moore RD, Miklos J, Knoll LD, Dupont M, Karram M, Kohli N, et al.: Monarc (TM) transobturator sling for the treatment of stress urinary incontinence: a prospective, multicenter study with one year follow-up. J Urol. 2006; 175: 110-11. 
18. Jiménez Calvo J, Hualde Alfaro A, Raigoso Ortega O, Cebrian Lostal JL, Alvarez Bandres S, Jiménez Parra J, et al. Our experience with mini tapes (TVT Secur and MiniArc) in the surgery for stress urinary incontinence. Actas Urol Esp. 2008; 32 : 1013-8.

19. Debodinance P, Delporte P: MiniArc: preliminary prospective study on 72 cases. J Gynecol Obstet Biol Reprod (Paris). 2009; 38: 144-8.

20. Martan A, Masata J, Svabík K: TVT SECUR System--tensionfree support of the urethra in women suffering from stress urinary incontinence--technique and initial experience. Ceska Gynekol. 2007; 72: 42-9.

21. Hazewinkel MH, Schilthuis MS, Roovers JP: Stress urinary incontinence in patients treated for cervical cancer: is TVTSecur a valuable treatment option? Int Urogynecol J Pelvic Floor Dysfunct. 2009; 20: 357-9.

22. Ghoniem GM, Kapoor DS: Nonautologous sling materials. Curr Urol Rep. 2001; 2: 357-63.

23. Amid PK, Lichtenstein IL, Shulman AG, Hakakha M: Biomaterials for "tension-free" hernioplasties and principles of their applications. Minerva Chir. 1995; 50: 821-6.

24. Yildirim A, Basok EK, Gulpinar T, Gurbuz C, Zemheri E, Tokuc $\mathrm{R}$ : Tissue reactions of 5 sling materials and tissue material detachment strength of 4 synthetic mesh materials in a rabbit model. J Urol. 2005; 174: 2037-40.

25. Bazi TM, Hamade RF, Abdallah Hajj Hussein I, Abi Nader K, Jurjus A: Polypropylene midurethral tapes do not have similar biologic and biomechanical performance in the rat. Eur Urol. 2007; 51: 1364-73; discussion 1373-5.
26. Cosson M: Risk of infection and prostheses: time out or a red flag?. J Gynecol Obstet Biol Reprod (Paris). 2004; 33: 559-60.

27. Versi E, Harvey MA, Cardozo L, Brincat M, Studd JW: Urogenital prolapse and atrophy at menopause: a prevalence study. Int Urogynecol J Pelvic Floor Dysfunct. 2001; 12: 107-10.

28. Riccetto $C$, Miyaoka $R$, de Fraga $R$, Barbosa R, Dambros M, Teixeira $A$, et al.: Impact of the structure of polypropylene meshes in local tissue reaction: in vivo stereological study. Int Urogynecol J Pelvic Floor Dysfunct. 2008; 19: 1117-23.

29. Ratner BD, Bryant SJ: Biomaterials: where we have been and where we are going. Annu Rev Biomed Eng. 2004; 6: 41-75.

30. Xia Z, Triffitt JT: A review on macrophage responses to biomaterials. Biomed Mater. 2006; 1: R1-9.

31. Hanson D, Langemo D, Thompson P, Anderson J, Hunter S: Understanding wound fluid and the phases of healing. Adv Skin Wound Care. 2005; 18: 360-2.

32. Morgan JE: A sling operation, using Marlex polypropylene mesh, for treatment of recurrent stress incontinence. Am J Obstet Gynecol. 1970; 106: 369-77.

Correspondence address: Dr. Cássio Riccetto

Rua Herman Muller, 429 Americana, Sao Paulo, 13465-630, Brazil E-mail: cassioriccetto@gmail.com

\section{EDITORIAL COMMENT}

In this elegant study by Palma et al. authors tested the resistance of different anchoring systems in several commercially available models of mini slings by implanting each anchoring device under the subcutaneous tissue of rat abdominal wall and evaluating them under a tension meter. Ophira ${ }^{\circledR}$ mini sling seems to deliver the most adequate design for the purpose of maintaining the suburethral polypropylene mesh on site with a delicate, fine, multi-spiky fishbonelike format suggesting that the more contact the implant has with host tissue the better is its fixation. This contact must be, however, delivered in an intelligent manner as to provide immediate adherent capacity to the anchoring system turning it less dependent on tissue interaction which tends to improve throughout time. Under this point of view, it seems logical that the "T" design proposed by Prosurg ${ }^{\circledR}$ would deliver less satisfying results.

Obviously, these results need to be confirmed in clinical setting, which implies a different scenario where dynamic and uneven strengths within the pelvic rim pull the sling device and might dislodge it.

\footnotetext{
Dr. Ricardo Miyaoka State University of Campinas Division of Urology E-mail:rmiyaoka@uol.com.br
} 


\section{EDITORIAL COMMENT}

Following the worldwide trend to adopt minimally invasive procedures, the single incision slings or the mini-slings have been developed. There is no doubt that the main issue of the third generation of the midurethral slings is how to ensure the primary fixation of the tape in order to maintain the sling in proper position while the healing process is completed. Precisely at this point devices differ. This initial biomechanical study has shown that the multipoint fish bonelike polypropylene fixation device is related to a greater initial tensile resistance compared to the others in an in vivo model, but in clinical practice the minimum tensile resistance to stabilize the tape has not been defined yet. On the other hand, it was also observed a significant increase in tensile resistance for all devices during

\section{REFERENCES}

1. Abdel-Fattah M, Ford JA, Lim CP, Madhuvrata P: Singleincision mini-slings versus standard midurethral slings in surgical management of female stress urinary incontinence: a meta-analysis of effectiveness and complications. Eur Urol. 2011; 60: 468-80. the furst postoperative month. This is a very important information that should be considered when counseling the patients; although these procedures can be performed in an outpatient basis, the post-operative care should be the same as those for the others midurethral slings. Recent literature showed that single incision slings, addressed to obturator internous muscle, are associated with inferior patient-reported and objective cure rates on the short-term followup, when compared with others midurethral slings (1). This result suggests that the best local and / or form of anchoring the mesh have not been reached yet. In conclusion, the main issue of the single incision slings persists and more biomechanical and clinical studies are needed to clarify this point.

\author{
Dr. José Tadeu Nunes Tamanini \\ Department of Medicine \\ UFSCar - Federal University of Sao Carlos \\ Ana Maria Homem de Mello Bianchi \\ Post Graduating Student / Urogynecological Unit \\ Faculty of Medicine \\ Unifesp - Federal University of Sao Paulo \\ E-mail: tadeutamanini@gmail.com
}

